\title{
PERBANDINGAN SISTEM PUSAT DAN DESENTRALISASI PENATAAN PAJAK
}

\author{
NOVI NATALIA PADANG \\ Fakultas Ekonomi Program Studi Akuntansi Universitas Katolik Santo Thomas \\ novipadang06@gmail.com
}

\begin{abstract}
ABSTRAK
Tujuan dari penelitian ini adalah untuk mengetahui perbandingan sistem sentralisasi dan desentralisasi administrasi perpajakan. Metode penelitian menggunakan metode studi pustaka yaitu metode pengumpulan data dengan melakukan penilaian terhadap sumber seperti membaca buku, internet seperti jurnal dan artikel yang berkaitan dengan masalah. Penggunaan desentralisasi efektif untuk administrasi perpajakan. Batasan penelitian ini menggunakan sumber referensi penelitian sebelumnya. Awalnya penelitian ini menggunakan peraturan perundang-undangan yang berlaku di Indonesia.
\end{abstract}

Kata Kunci: Pajak, Sentralisasi, Desentralisasi.

\section{PENDAHULUAN}

Banyak negara, termasuk namun tidak terbatas pada kelompok negara berkembang dan transisi, telah memusatkan otoritas perpajakan dan administrasi perpajakan dengan pemerintah pusat. Namun, ada anggapan bahwa pemerintah daerah di seluruh dunia sedang tumbuh Bahl (1999), bahwa mereka tidak lagi memerlukan bimbingan dan kendali pemerintah pusat agar mereka dapat memberikan kontribusi positif untuk penyediaan dan penyampaian layanan pemerintah, bahwa mereka dapat dan harus memikul lebih banyak tanggung jawab untuk membiayai layanan tersebut, dan bahwa membawa keputusan lebih dekat ke rakyat, para pemilih, akan meningkatkan efisiensi, efektivitas, dan daya tanggap pemerintah.

Karena negara-negara memberikan kewenangan yang signifikan kepada pemerintah lokal dan regional untuk memungut pajak dan tanggung jawab untuk membiayai secara mandiri bagian yang lebih besar dari biaya layanan yang mereka sediakan, ada dua pelajaran penting dari pengalaman internasional yang harus mereka ingat. Pertama, pengalaman internasional dengan jelas menunjukkan bahwa pajak tidak perlu dikelola oleh pemerintah yang memungutnya. Memberikan kewenangan pajak yang berarti kepada pemerintah subnasional memberi mereka kekuasaan untuk menyesuaikan ukuran anggaran mereka dan untuk menetapkan bagaimana beban pajak dari pembiayaan anggaran tersebut akan didistribusikan. Dapat dikatakan bahwa memberikan kewenangan kepada daerah untuk menyesuaikan tarif pajak yang menghasilkan pendapatan bagi mereka memberikan otonomi fiskal yang memadai.

Dalam rangka meningkatkan pendapatan asli daerah dalam rangka penyelenggaraan otonomi, Pemerintah melakukan berbagai kebijakan perpajakan daerah, antara lain dengan menetapkan UU No. 34 Tahun 2000 tentang Perubahan atas Undang-Undang Nomor 18 Tahun 1997 tentang Pajak dan Retribusi Daerah. Pemberian kewenangan dalam pengenaan pajak dan retribusi daerah, diharapkan dapat semakin mendorong pemerintah daerah terus berupaya mengoptimalkan PAD, terutama yang bersumber dari pajak dan retribusi daerah.

\section{METODOLOGI PENELITIAN}

Metode penelitian yang digunakan adalah metode studi kepustakaan, yaitu metode pengumpulan data dengan melakukan penilaian terhadap sumber-sumber seperti bacaan bokk, internet seperti jurnal dan artikel yang berkaitan dengan masalah.

\section{HASIL DAN PEMBAHASAN}

\section{Membandingkan Alternatif}

Pajak daerah dapat dipungut oleh pemerintah yang memungutnya atau mungkin dipungut oleh administrator pajak dari pemerintah lain. Kisaran praktek nasional cukup luas dan memberikan bukti yang cukup besar tentang konsekuensi dari pilihan administratif tersebut. 


\section{Administrasi Terpusat}

Administrasi perpajakan terpusat dapat memberikan layanan berkualitas tinggi dengan biaya rendah bagi pemerintah subnasional, tetapi dapat mengurangi transparansi dan akuntabilitas publik untuk kebijakan perpajakan, dapat menunda arus kas ke pemerintah subnasional, dan akan mengurangi otonomi daerah. Bukti dari tinjauan internasional tentang alternatif administrasi perpajakan menunjukkan kesimpulan spesifik berikut tentang administrasi terpusat:

a. Sejauh ada skala ekonomi dalam proses administrasi perpajakan, administrasi terpusat meningkatkan kemungkinan penghematan biaya ini akan terwujud. Administrasi lokal independen yang lebih kecil dapat memperoleh ekonomi dengan mengadakan kontrak dengan entitas yang lebih besar atau dengan menggabungkan operasi dengan administrasi lain, tetapi hal ini kurang pasti terjadi dibandingkan jika administrasi terpusat.

b. Administrasi terpusat menyediakan struktur tunggal untuk menangani semua pembayar pajak di seluruh negeri. Dengan kontrol administratif yang baik di sistem pusat, prosedur dan proses yang sama akan diikuti di mana pun di negara ini. Itu memungkinkan adanya sistem informasi tunggal untuk melacak pembayar pajak dan kegiatan ekonomi mereka dan satu nomor identifikasi wajib pajak untuk semua pajak. File master tunggal dengan semua data yang relevan akan memberikan alat yang kuat untuk penegakan dan pengumpulan melalui pencocokan di seluruh jenis pajak. Nomor identifikasi wajib pajak tunggal akan membantu penegakan dan proses pendaftaran tunggal ke dalam sistem informasi akan menyederhanakan kepatuhan wajib pajak.

c. Sistem terpusat tunggal meningkatkan kemungkinan pembayar pajak akan menerima perlakuan yang konsisten dan tidak bias oleh otoritas pajak, tidak peduli di mana di negara tersebut entitas atau aktivitas kena pajaknya berada. Perlakuan yang seragam tanpa memperhatikan di mana wajib pajak berada atau kepada siapa wajib pajak tersebut dapat meningkatkan kemungkinan bahwa administrasi akan dipandang adil dan tidak bermain favorit dan tidak akan miring untuk memberikan "kesepakatan" kepada wajib pajak tertentu. Karena pemerintah daerah lebih dekat dengan masyarakat, selalu ada kekhawatiran bahwa pemerintah akan menjadi favorit dan informasi rahasia wajib pajak akan disalahgunakan ketika orang yang menangani pengembalian mengenal wajib pajak. Dengan administrasi pusat, di mana pun wajib pajak berada di suatu negara, wajib pajak akan tunduk pada rezim administrasi yang persis sama dan tidak ada yang akan menikmati keunggulan kompetitif karena perbedaan administratif. Persepsi administrasi yang seimbang kemungkinan besar berkontribusi pada kemungkinan kepatuhan terhadap pajak.

d. Organisasi pusat dapat memfasilitasi rotasi personel, komponen penting dari pengendalian internal untuk mengurangi potensi korupsi. Dalam unit administrasi yang lebih kecil, mungkin ada terlalu sedikit auditor yang memiliki keterampilan yang memadai relatif terhadap jumlah penugasan yang rumit untuk mempertahankan rotasi reguler untuk penugasan tersebut.

e. Administrasi pusat mengurangi jumlah titik kontak antara wajib pajak dan otoritas pajak dan, karena ada biaya overhead tertentu yang akan dikaitkan dengan pemungutan pajak, dapat mengurangi biaya administrasi dan kepatuhan untuk sistem pendapatan secara keseluruhan, pusat ditambah subnasional. Otoritas administratif tunggal menghilangkan kemungkinan bahwa wajib pajak akan bingung tentang organisasi pajak mana yang bertanggung jawab untuk menjawab pertanyaan, menerima pengajuan, penegakan, dan lain-lain.

f. Badan-badan administratif besar yang dihasilkan oleh sentralisasi mungkin menyediakan personel yang lebih berkualitas, mungkin mampu membayar gaji yang lebih tinggi (dan dengan demikian mengurangi daya tarik korupsi), memungkinkan personel untuk berspesialisasi pada tingkat yang tidak memungkinkan dengan unit-unit administrasi yang lebih kecil, dan mungkin memiliki anggaran yang memungkinkan teknologi informasi lebih canggih.

g. Administrasi perpajakan nasional yang terpusat dapat dilengkapi dengan lebih baik, secara legal dan dalam hal sumber daya, untuk menangani badan usaha nasional dan global. Badanbadan subnasional mungkin kewalahan dalam upaya menegakkan kepatuhan dari bisnis besar seperti itu. 
h. Administrasi perpajakan nasional yang besar dan terpusat akan lebih mampu menangani kegiatan kena pajak yang melintasi batas wilayah atau yurisdiksi lokal dalam negara.

i. Administrasi pusat dapat mengizinkan penerapan struktur yang lebih canggih dari beberapa pajak. Misalnya, lebih mudah bagi pemerintah daerah untuk mengelola pajak pendapatan berdasarkan "pendapatan yang diperoleh" atau gaji daripada pajak luas atas pendapatan dari sumber manapun dalam konsep Haig - Simons; yang pertama membutuhkan penegakan hukum terhadap pemberi kerja di yurisdiksi, tugas yang jauh lebih mudah daripada pelaporan yang lebih luas dari entitas di luar yurisdiksi yang hampir pasti dibutuhkan oleh yang terakhir.

j. Pemerintah pusat dapat memfasilitasi transfer pendapatan untuk mengurangi disparitas fiskal horizontal antar unit pemerintah daerah. Pendapatan dari pajak yang dikelola oleh pemerintah subnasional hampir selalu berada pada pemerintah yang mengumpulkan pendapatan, meninggalkan disparitas yang besar antar daerah dengan endowment basis pajak yang tinggi, sumber daya alam, industri berat, dll., dan mereka yang kekurangan dana abadi tersebut.

\section{Administrasi Subnasional Independen.}

Standar penting keuangan publik modern adalah prinsip subsidiaritas, gagasan bahwa tindakan pemerintah harus diambil di tingkat pemerintahan yang paling rendah, tingkat yang paling dekat dengan rakyat, di mana tujuan yang diinginkan dapat tercapai. Prinsip tersebut, ketika diterapkan pada administrasi perpajakan, mengisyaratkan bahwa administrasi perpajakan daerah dan daerah yang independen tidak boleh diberhentikan, tetapi harus dipertimbangkan sebagai alternatif lain dalam pelaksanaan kebijakan perpajakan nasional yang efisien, efektif, dan responsif. Casanegra de Jantscher (1990) menyatakan bahwa "administrasi pajak adalah kebijakan pajak" di negara berkembang. Hal yang sama juga berlaku di negara-negara transisi dan, mengingat variasi dalam syarat dan ketentuan penegakan hukum di suatu negara, juga berlaku untuk tingkat penting kebijakan pajak di negara mana pun. Pemerintah regional dan lokal, bahkan dalam satu negara, sangat bervariasi dalam hal ukuran, profesionalisme, dan perkembangan ekonomi. Hal ini membuat kesimpulan yang tepat tentang administrasi pajak independen menjadi sulit. Namun, pengalaman umum dengan administrasi pajak daerah dan lokal yang independen menunjukkan hal-hal berikut:

a. Keakraban dengan kondisi lokal dan kemudahan beradaptasi dengan kondisi lokal tersebut dapat memfasilitasi pendaftaran wajib pajak, pemungutan, dan penegakan banyak pajak.

b. Pemerintah daerah dapat menerapkan pajak atas kegiatan ekonomi yang berada di bawah ambang batas kepentingan pemerintah pusat karena pemerintah daerah telah terbiasa dengan lingkungan bisnis lokal dari informasi yang dihasilkan melalui proses perizinan dan peraturan daerah dan dapat menghasilkan pendapatan dengan membawa usaha kecil ke dalam pajak. sistem dengan biaya yang relatif rendah. Menerapkannya ke dalam sistem pajak daerah juga dapat membantu mobilisasi pendapatan pemerintah pusat jika ada pertukaran informasi antara pemerintah pusat dan daerah.

c. Ketika administrasi pajak daerah terpisah, jauh lebih mudah bagi pembayar pajak untuk melihat pemerintah mana yang memungut pajak apa - dan meminta pertanggungjawaban pemerintah yang sesuai. Transparansi bisa hilang ketika otoritas pusat mengelola pajak yang dipungut oleh tingkat pemerintahan yang lebih rendah. Para wajib pajak yang menerima tagihan pajak properti daerah / daerah gabungan atau menyiapkan SPT gabungan daerah / daerah seringkali tidak dapat dengan mudah membedakan apa yang pemerintah pungut bagian mana dari total tagihan pajak. Hal itu mengurangi sejauh mana otonomi fiskal meningkatkan akuntabilitas pilihan anggaran yang telah dibuat. Administrasi independen biasanya mengungkapkan tanggung jawab atas pajak yang dikenakan.

d. Otoritas pajak regional dan lokal yang independen dapat bertindak sebagai "kamar percobaan yang terisolasi" untuk administrasi pajak. Mereka dapat menginovasi pendekatan dan teknik baru, memanfaatkan kegesitan yang sering menjadi ciri organisasi yang lebih kecil. Beberapa pemerintah subnasional memiliki fleksibilitas dan kontrol yang lebih besar atas sumber daya daripada yang lain, beberapa memiliki administrator yang lebih kreatif daripada yang lain, dan beberapa memiliki lingkungan yang lebih baik untuk eksperimen daripada yang lain. 
e. Administrasi independen dapat memberikan kendali yang lebih cepat dan lebih pasti kepada pemerintah yang mengenakan pajak atas pendapatannya. Seperti yang diakui Veehorn dan Ahmad, administrasi pusat berarti bahwa "pemerintah daerah mungkin merasa bahwa mereka hanya memiliki sedikit kendali atas penerimaan." (1997) Dengan pemerintahan yang mandiri, pemerintah tidak perlu menunggu penyaluran dari pemerintah pusat karena memiliki kendali atas dana segera setelah wajib pajak melakukan pembayaran.

f. Pemerintah subnasional menyukai tenaga kerja yang disediakan oleh administrasi independen. Tujuannya adalah untuk menciptakan lapangan kerja atau setidaknya kesempatan untuk mendapatkan penghasilan bagi seseorang yang mungkin saja menganggur.

g. Pemerintah daerah mungkin tidak puas dengan standar pusat penegakan pajak dan pemerintah daerah mengizinkan mereka untuk menerapkan kebijakan penegakan yang berbeda. Dengan kata lain, pemerintah daerah mungkin memiliki pandangan berbeda tentang distribusi yang tepat dari pajak yang tidak dipungut; administrasi lokal independen memungkinkan kebijakan penegakan untuk mencerminkan perbedaan-perbedaan ini.

\section{Dilema Desentralisasi}

Keputusan untuk mendesentralisasikan administrasi pajak daerah sering kali melibatkan, seperti yang dijelaskan Dillinger (1991), "pertukaran antara ketidakpedulian dan ketidakmampuan." Ketika pemerintah pusat tidak menerima pendapatan dari administrasi pajak, pajak tersebut kemungkinan besar akan menerima perhatian yang kurang dari yang diberikan pajak yang menghasilkan pendapatan bagi pemerintah pusat. Tetapi pemerintah daerah mungkin memiliki kapasitas yang lebih rendah untuk mengelola pajaknya daripada pemerintah pusat, dalam hal personel yang berkualifikasi, teknologi, dan kemampuan untuk menghadapi bisnis besar. Karenanya tradeoff: pemerintah pusat mampu tetapi kurang tertarik pada koleksi lokal dan pemerintah daerah sangat tertarik dengan yang kurang mampu.

Itulah dilema mendasar dalam memberikan kewenangan baru kepada pemerintah daerah untuk administrasi perpajakan mereka sendiri: pemerintah daerah atau daerah kemungkinan tidak memiliki kapasitas penuh untuk mengelola pajak mereka sendiri jika mereka belum pernah melakukannya sebelumnya dan pemerintah pusat enggan untuk mengizinkan sendiri administrasi tanpa menunjukkan kapasitas administratif. Oleh karena itu, ketika mempertimbangkan apakah pemerintah subnasional akan mampu menjalankan pemerintahan sendiri, pertanyaannya harus sejauh mana mereka mampu melakukan tugas-tugas tersebut, bukan apakah mereka saat ini siap untuk melakukan pekerjaan tersebut. Ini tentunya berarti bahwa pelatihan dan bantuan teknis harus menyertai desentralisasi kewenangan administratif yang besar. Singkatnya, ketidakmampuan bisa diperbaiki, tetapi ketidakpedulian itu permanen.

\section{Gambaran Umum Sistem Administrasi}

Dalam praktiknya, pajak yang diberikan kepada pemerintah subnasional dapat dikumpulkan secara terpusat, secara independen oleh penerima pendapatan, atau melalui pengaturan administratif kooperatif. Ada banyak contoh dari kebanyakan pengaturan administratif. Beberapa di antaranya akan dijelaskan di bagian selanjutnya.

\section{Administrasi Pusat}

Administrasi pajak tunggal mengelola semua pajak di banyak negara, termasuk pajak yang dipungut oleh pemerintah pusat dan daerah. Terkadang hanya pemerintah pusat yang memiliki otoritas perpajakan, dalam hal ini administrasi tunggal adalah satu-satunya pilihan yang masuk akal - kebijakan perpajakan pemerintah pusat harus dijalankan secara konsisten dan seragam di seluruh negeri. Argumen keseragaman juga kuat ketika pajak telah diadopsi secara terpusat untuk didedikasikan dan dibagikan kepada pemerintah daerah atau lokal. Juga nyaman ketika pemerintah subnasional diizinkan untuk memungut tarif tambahan (atau didukung) pada basis nasional. Dengan administrasi terpusat, pemerintah pusat - baik secara terpusat atau melalui cabang-cabang daerah yang bergantung - memungut pajak yang dipungut oleh pemerintah pusat, pendapatan dari mana dapat membiayai pelayanan pemerintah pusat, dapat didistribusikan ke pemerintah daerah atau daerah melaluiprogram hibah bersyarat atau tidak bersyarat, atau dapat dibagikan melalui 
formula dengan pemerintah yang lebih rendah dan juga memungut pajak yang mungkin dikenakan oleh pemerintah subnasional.

\section{Administrasi Lokal Independen.}

Otoritas subnasional yang independen baik untuk memberlakukan undang-undang perpajakan (memilih pajak, menentukan basis, menetapkan tarif, dll.) Dan untuk mengelola pajak yang telah diberlakukan memberi unit subnasional ini tingkat otonomi fiskal yang lebih tinggi karena pemerintah daerah atau daerah mengontrol kedua rancangan tersebut. struktur pajak dan bagaimana struktur itu akan diterapkan. Dalam banyak kasus, pajak yang dikelola secara independen untuk otoritas subnasional tidak dipungut oleh pemerintah nasional, sehingga administrasi independen menambah keragaman skema pendapatan negara secara keseluruhan, selain memberikan otonomi fiskal.

Pemerintah subnasional membutuhkan kapasitas administratif yang memadai untuk pemungutan pajak yang adil dan efisien yang menjadi tanggung jawab pemungutannya. Karena administrasi itu sendiri adalah elemen dari otonomi pendapatan, fakta bahwa administrasi terpusat mungkin lebih murah untuk beberapa pajak, mungkin meningkatkan beberapa aspek keadilan distribusi, atau mungkin menghasilkan pendapatan tambahan bukanlah bukti yang menentukan untuk mendikte administrasi pusat.

\section{Batasan dan Implikasi}

Keterbatasan penelitian ini menggunakan sumber referensi penelitian sebelumnya.

\section{KESIMPULAN}

Assignment of reasonable taxing powers helps give a government control over its fiscal destiny. It allows the government, acting for its citizens, choice over its level of spending and how that spending will be financed from segments of its economy. That is an important element for fiscal autonomy. From the revenue side of the public economy, fiscal autonomy (and responsibility) is greatest when the subnational government chooses what taxes it will levy, defines the bases it will use, sets the rate and preference structure for those bases, and administers the taxes that have been adopted. While surcharges on central tax bases can give a considerable degree of fiscal autonomy without some of the problems that full autonomy can create, subnational governments may not agree, if given the choice, that the autonomy thus given is adequate. In particular, they may be concerned that a government not receiving the revenue from a tax that it administers is likely to feel less urgency in collection of or for reform of that tax than are those using the revenue to finance their operations. They may feel that administration in practice is inextricably intertwined with tax policy and that, without having choice over administrative decisions, they lack appropriate fiscal autonomy. Local governments can be capable of independent administration of the taxes they levy if the governments provide political will and operational support.

\section{DAFTAR PUSTAKA}

Azizul Kholis, Iskandar Muda, and Mummar Khaddafi. Influence of population, gross domestic product, government sukuk and sharia mutual funds to the investment yield sharia insurance in Indonesia.

Bahl, Roy W. 1999. "Fiscal Decentralization as Development Policy," Public Budgeting \& Finance IXX (Summer): 59-75.

Bahl, Roy W. and Johannes F. Linn. 1992. Urban Public Finance in Developing Countries. Washington, D.

C.: World Bank.

Casanegra de Jantscher, Milka. 1990. "Administering the VAT," in Malcolm Gillis et al (ed.), Value Added Taxation in Developing Countries. Washington, D. C.: World Bank. 
Dillinger, William. 1991. Urban Property Tax Reform. Washington, D. C.: World Bank. Republik Indonesia "No Keuangandan RAPBN TahunAnggaran 2011".

Iskandar Muda, Mohd. Heikal, and Muammar Khaddafi. Influence government sukuk and sharia mutual funds To the investment yield sharia insurance in Indonesia. 